\title{
Management of Incorrect Public Works Cost Estimations for Japan's Local Governments
}

\author{
Nobuo Nishi (西 喜士) \\ Department of Urban and Civil Engineering, Tokyo City University, \\ 1-28-1 Tamazutsumi, Setagaya-ku, Tokyo 158-8557, Japan \\ Masaru Minagawa (皆川 勝) \\ Department of Urban and Civil Engineering, Tokyo City University, \\ 1-28-1 Tamazutsumi, Setagaya-ku, Tokyo 158-8557, Japan \\ cross $^{\text {ref }}$ http://dx.doi.org/10.5755/j01.ppaa.20.1.27272
}

\begin{abstract}
Local governmental public works departments frequently engage in planning, cost estimation, ceiling price determination, bidding, contracting, construction, supervision, and inspection activities for various building projects. However, despite all this work, local governments in Japan often cancel bids for project design and construction due to incorrect cost estimations. Consequently, facilities are often not constructed as planned, resulting in adverse impacts on public services and decreased government employees' motivation. While local governments have conducted internal investigations to prevent incorrect estimations, a firm diagnosis model and preventive measures have not been developed. This study analyses the various causes of incorrect cost estimations and subsequently examines the resulting social problems. We propose improved human resources development management and organisational management techniques using the V-mSELC model - an error analysis model designed to address incorrect cost estimations. The study aims to aid public works professionals and interested scholars.
\end{abstract}

Keywords: incorrect cost estimation, local governments in Japan, V-mSELC model, organisation management, human resources development management

Raktažodžiai: neteisingas išlaidu ịvertinimas, vietos valdžios institucijos Japonijoje, $V$ mSELC modelis, organizacijos valdymas, žmogiškuju ištekliu plètros valdymas

\section{Introduction}

Local governments in Japan often cancel bids owing to incorrect cost estimations corresponding to project design. Unless requested by citizens, most local governments do not officially disclose bid cancellation information as it is considered negative information. As a result, planned public works are not built, which leads to adverse impacts on public services and decreasing staff motivation. While local governments conduct internal investigations to prevent incorrect cost estimations, none have developed a firm diagnosis model and preventive measures. Furthermore, there are no academic studies to aid them in addressing this issue.

Local governments frequently engage in planning, cost estimation, ceiling price determination, bidding, contracting, construction, supervision, and inspection activities for various building projects. Cost estimation is the task of determining the ceiling price of a project in a bidding procedure through which the contractor is selected. In this project flow, determining the ceiling price is an integral part of the bidding process, as the ceiling price limits the maximum bid and is used to determine the minimum bid (Ohashi, 2014; Kinoshita, 2017). In countries such as the United States and France, there is no ceiling price system with an upper limit for bids, as there is in Japan. Other countries have set ceiling prices to guide budget control (Ding, 2016; Netscher, 2017). Thus, in other countries, it is difficult to find records on incorrect cost estimations. If the ceiling price is incorrectly determined, construction will be carried out under an incorrect contract. This problem can be solved 
by either reviewing the ceiling price system or preventing mistakes in the estimation. In the case of the former, researchers have discussed the current bidding contract system (Ohashi, 2014; Kinoshita, 2017). This study excludes discussions regarding the bid contract system. Instead, we focus on the second method, namely, preventing incorrect cost estimations.

Human error is a known issue, and local governments often halt bidding in the face of incorrect cost estimations - arising owing to human error, which adversely affects services for residents. This has been discussed at great length in existing literature (Nikkei Construction, 2010, 2013a, 2013b). Moreover, studies indicate that "mistakes at work" is a highly ranked factor that reduces staff motivation (Mynavi Corporation, 2017; Max Blog, 2016; Tokyo Future University, 2018). In the jurisdiction where the first author works, there were four occurrences of cost estimation errors per month. Therefore, incorrect cost estimation is a significant social problem that must be studied and resolved academically.

Through this study, we investigate incorrect cost estimations by the local government of a city in Japan where the first author works, and we probe into this phenomenon that has become a social issue in recent years. In addition, we examine human resources development management and organisation management using the "V-mSELC model" to analyse and take measures against incorrect cost estimation.

This study adds fresh insight to papers that have been peer-reviewed and submitted by the Japan Society of Civil Engineers and the International Journal of Civil Engineering. These papers have already been published in academic conferences and international journals; they predominantly targeted Japanese civil engineers and examined only a small number of people. This study aims to benefit people working in public works institutions around the world, and its findings are structured to be made accessible to all interested readers.

This study first analyses the various causes of incorrect cost estimation, following which the social aspect of the problem is examined. Finally, human resources development management and organisational management are proposed using the V-mSELC model, which is an error analysis model designed to address incorrect cost estimation. The structure of the paper is as follows. The materials and methods are described for each item of research related to the cost estimation. The results and discussion are then provided. Finally, concluding remarks are offered.

\section{Incorrect cost estimation}

The literature has newly classified the causes of incorrect cost estimation (Nishi et al., 2020). The original data used for the new classification are taken from a report compiled by "City K" in 2015 that categorised the causes into three categories: insufficient knowledge, lack of attention, and other (Kawasaki City, 2016). Table 1 shows the classification of the causes of incorrect cost estimation. In preparing Table 1, we referred to Takagi's (2012) study that classified the causes of human error in the construction industry. In our study, a civil engineer from a local government was the subject of the incorrect cost estimation. The Category 1 item "Ignorant, Inexperienced, Unfamiliar" clearly corresponds to "Insufficient knowledge"; however, the remaining 11 categories present a wide variety of human error causes and are not general items, and so judgments are different for each person during classification. Therefore it was decided that the errors should be classified into two categories_- "Insufficient knowledge" and "Other than lack of knowledge."

Table 1. Causes and unique classifications of human errors in the construction industry

\begin{tabular}{|c|c|c|}
\hline CLASSIFICATION & ITEM & UNIQUE \\
& & CLASSIFICATION \\
\hline 1 & Ignorance/inexperience/unfamiliar & Insufficient knowledge \\
\hline 2 & Danger neglected/accustomed & Other than lack of knowledge \\
\hline 3 & Carelessness \\
\hline
\end{tabular}




\begin{tabular}{|c|c|c|}
\hline CLASSIFICATION & ITEM & UNIQUE \\
\hline 4 & Lack of communication \\
\hline 5 & Collective defect \\
\hline 6 & Shortcut/short action instinct \\
\hline 7 & Scene action instinct \\
\hline 8 & Panic \\
\hline 9 & Illusion \\
\hline 10 & Middle-aged or senior \\
\hline 11 & Awareness reduction owing to monotonous work \\
\hline 12 & Fatigue \\
\hline
\end{tabular}

Source: Authors.

Table 2 shows the results of the reclassification based on this concept. Approximately $15 \%$ or more of incorrect cost estimation causes were due to "insufficient knowledge," while more than 70\% were owing to "other than lack of knowledge." It was found that both causes accounted for a high ratio of two digits or more. In the former case, preventing such errors would require better management measures for human resources development, for example, by improving the quality of education that civil engineers receive. In the latter case, it would be necessary to consider organisational management practices, such as establishing a system to eliminate simple mistakes. "Near miss projects" are defined as cases in which an incorrect cost estimation was noticed at the stage of cost estimations and prevented in advance.

The following section presents an analysis of how incorrect cost estimations became a social problem in recent years.

Table 2. Results of reclassification in the literature

\begin{tabular}{|c|c|c|c|}
\hline & $\begin{array}{c}\text { BID CANCELLATION } \\
\text { PROJECT (2015) }\end{array}$ & $\begin{array}{c}\text { NEAR MISS PROJECT } \\
(2015)\end{array}$ & $\begin{array}{c}\text { BID CANCELLATION } \\
\text { PROJECT (2009, 2010, 2011) }\end{array}$ \\
\hline $\begin{array}{c}\text { Insufficient } \\
\text { knowledge }\end{array}$ & $30 \%$ & $23 \%$ & $14 \%$ \\
\hline $\begin{array}{c}\text { Other than lack of } \\
\text { knowledge }\end{array}$ & $70 \%$ & $77 \%$ & $86 \%$ \\
\hline
\end{tabular}

Source: Authors.

\section{Relationship between recent public policy and incorrect cost estimation in local governments}

Around the year 2000, incorrect cost estimations for public works occurred frequently, but it was not recognised as a social problem, which recent literature reports (Nikkei Construction, 2010, 2013a, 2013b). First, we examined the problem of incorrect cost estimation from the viewpoint of public policy. Nishi et al. (2020) analysed the relationship between incorrect cost estimations in local governments and current public policies such as the minimum price system, the administrative opinion system, and the estimation opinion system. The names of the systems differ depending on each local government, but there is no significant difference in the contents of the systems.

\section{Minimum price system}

The minimum price system invalidates a bid that does not reach a certain percentage of the predetermined price, even if the bid is placed at the lowest price within the limited range of the predetermined price. In such a case, the person who has submitted the lowest price, which is above 
the minimum limit price, is determined as providing a successful bid. In the bidding system, there is an upper limit system of the ceiling price and a lower limit system of the minimum limit price. As construction companies need to estimate upper and lower price limits accurately, it is necessary to treat selection errors in the cost estimation data list and miscalculation of quantities as major problems in incorrect cost estimations. However, in City K, the "Minimum Price Handling Guidelines for Certain Municipal Construction Contracts" came into effect on April 1, 2006, and they have not been systematised to suit present times. Therefore, this system cannot be said to have led to incorrect estimations becoming a social problem.

\section{Administrative opinion system}

The administrative opinion system allows for public opinions to be shared with local governments. This recent mechanism made it easier for citizens to express their opinions. Until this system was established, citizens could not easily comment on the administration. In response to the flow of information disclosure, construction companies requested that the details of cost estimation be distributed to local governments before bidding was released, following which local governments began disclosing information on cost estimations. With the decrease in public investment, a competitive environment in public works caused construction companies to demand more detailed disclosure of the data list of cost estimations. This made it possible for construction companies with low construction capacities to make successful bids.

\section{Cost estimation opinion system}

In the cost estimation opinion system, construction companies participating in the bidding can check the cost estimation contents and share their opinions to ensure transparency in the bidding process. If the contents of the cost estimation are found to be incorrect, and the contract is inappropriate, the bidding will halt. This system was introduced in City K in 2012, and similar systems have been introduced in other local governments. With the establishment of the administrative and cost estimation opinion systems, local governments have become more positive in their approach. By allowing municipalities to publish the cost estimation information, construction companies can calculate the planned and minimum prices for public works and point out cases of incorrect cost estimation. With the introduction of such systems, incorrect cost estimation began to be viewed as a social issue. When other countries begin to use the Japanese system introduced in this study, appropriate human resources development management and organisational management should be studied and constructed in advance to avoid mistakes in administrative management.

\section{Relationship between public works data and incorrect cost estimation}

Nishi et al. (2020) analysed the relationship between the number of civil engineers, the number of construction contracts, and the type of construction in City $\mathrm{K}$ and incorrect cost estimation. These three items have been selected for this study because they affect cost estimations.

\section{Changes in the number of civil engineers and construction contracts (civil engineering) in City $K$}

Figure 1 shows the rate of change in the number of civil engineers and the number of construction contracts (civil engineering) in City K from fiscal years 2011 to 2017. As the burden of cost estimation depends on the number of construction contracts rather than the construction cost, the construction contract basis was used instead of the construction cost basis. This is because some types of construction can be more expensive than others. Owing to the information disclosure agreement, raw numerical data cannot be published. The values for 2011 of civil engineers and the number of construction contracts (civil engineering) are used as the reference values, and the values for other years were divided by the reference values. 


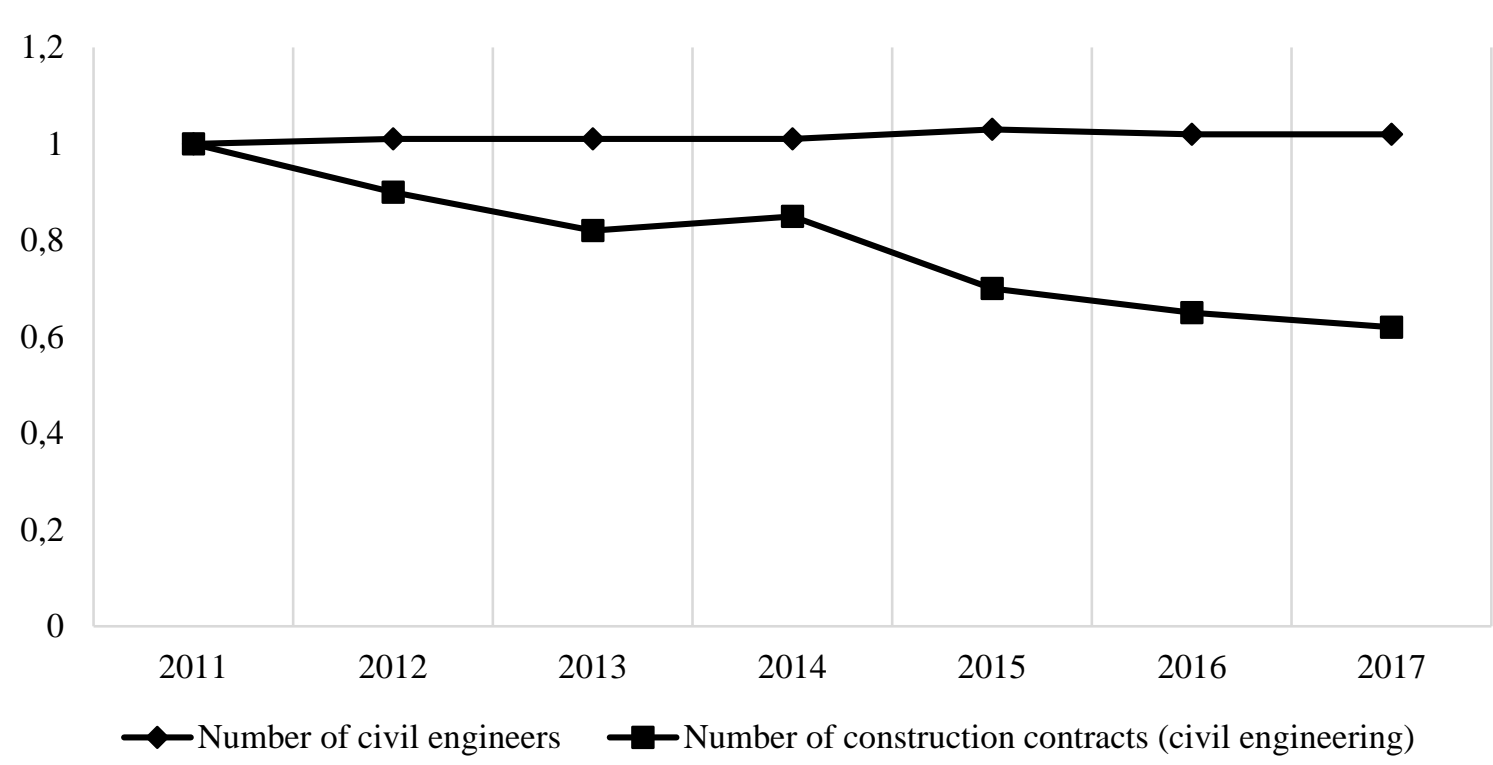

Fig. 1. Number of civil engineers and construction contracts

Source: Authors.

Figure 1 shows that the number of construction contracts (civil engineering) has decreased despite the number of civil engineers remaining fairly constant. Judging by the numbers alone, the burden on civil engineers regarding the costs should have been reduced. However, many incorrect cost estimations occurred in City K in 2015 (Kawasaki City, 2016). In other words, the reason for incorrect cost estimations cannot be pinned easily on the shortage of civil engineers or the decrease in the number of construction contracts. It is, therefore, necessary to analyse the case based on the type of construction.

\section{New construction and maintenance and repair work}

Table 3 shows a comparison of the workflow of new construction, maintenance, and repair work. New construction is relatively simple, given that an empty site is simply used for constructing a new civil engineering structure. When creating a standard cost estimation criterion, it is easy to match the subject of the construction survey with the situation of the ordering site. Therefore, the actual price is often the same as the price calculated by the local government. Many construction companies aim to receive orders for new construction because the sites are easier to manage, and the operating profits are higher. Even civil engineers at local governments prefer new construction work. In many cases, however, junior staff without sufficient civil engineering skills are placed in charge.

Maintenance and repair work, in contrast, often involve complicated removal work. They also entail temporary construction under adverse conditions. In other words, cost estimation is a challenge in many such cases without a deep understanding of the construction contents. Moreover, ample time is required for the cost estimation. In maintenance and repair work, it is often not possible to make a clear judgment of whether the standard cost estimation criteria can be met. Cancelled tenders are mostly those requiring maintenance and repair work (Komada et al., 2010). For example, maintenance and repairs account for about $27 \%$ of the works for which bids were invalidated (Komada et al., 2010). In many cases, the manager of the cost estimation department assigns the cost estimation of maintenance and repair work to a senior staff member with civil engineering skills, as an experienced engineer is less likely make mistakes. 
Table 3. The flow of new construction and maintenance and repair work

\begin{tabular}{|c|c|}
\hline NEW CONSTRUCTION & MAINTENANCE AND REPAIR WORK \\
\hline $\begin{array}{c}\text { Simple field survey } \\
\downarrow \\
\text { Simple structural calculations } \\
\downarrow \\
\text { New construction } \\
\downarrow \\
\text { Construction completed }\end{array}$ & $\begin{array}{c}\text { Collection of data for existing facilities } \\
\downarrow \\
\text { Complex field surveys } \\
\downarrow \\
\text { Complex structural calculations } \\
\downarrow \\
\text { Scaffolding installation } \\
\downarrow \\
\text { Removal of existing facilities } \\
\downarrow \\
\text { Maintenance and repair work } \\
\downarrow \\
\text { Scaffold removal } \\
\downarrow \\
\text { Construction completed }\end{array}$ \\
\hline
\end{tabular}

Source: Authors.

\section{Changes in maintenance and repair work in public works}

Table 4 shows the proportion of public infrastructure (constructed facilities) that is 50 years old or more. It is clear from Table 4 that since 2013, the number of facilities that have been in service for 50 or more years has significantly increased. These facilities were built during periods of high economic growth. This indicates that if the planned maintenance work is not undertaken, the facilities will not be available in the future, eventually leading to a decline in public services. In recent years in Japan, apart from incorrect cost estimation, there is the social issue of undertaking planned and regular maintenance and repair work immediately. However, local governments are systematically carrying out maintenance and repair work within a usually insufficient budget.

Table 4. Percentage of public infrastructure constructed more than $\mathbf{5 0}$ years ago

\begin{tabular}{|c|c|c|c|}
\hline FACILITY TYPE & 2013 & 2023 & 2033 \\
\hline Road bridge & $18 \%$ & $43 \%$ & $67 \%$ \\
\hline Tunnel & $20 \%$ & $34 \%$ & $64 \%$ \\
\hline River management facilities & $25 \%$ & $43 \%$ & $24 \%$ \\
\hline Sewer pipe & $2 \%$ & $9 \%$ & $58 \%$ \\
\hline Quay & $8 \%$ & $32 \%$ & $50 \%$ \\
\hline
\end{tabular}

Source: Ministry of Land, Infrastructure, Transport, and Tourism, 2010

In recent years, where cases of complicated maintenance and repair work are rising in number, it has become complicated to determine the specific causes of incorrect cost estimations. Here, as mentioned earlier, maintenance and repair work contracts are typically handed over to senior staff to prevent incorrect cost estimations and minimise errors. However, this may be a blind spot because senior staff may have handled only simple construction work during their term as junior staff and have little experience in estimating complex maintenance and repair work. Therefore, it has been challenging to cope with the rapidly increasing number of ageing facilities since 2013. The Ministry of Land, Infrastructure, Transport, and Tourism (2014) describes the current issues regarding human resources development related to maintenance and repair work. However, their evaluation is not 
limited to the experience of junior staff, the decline in technical skills, and the shortage of engineers. Cause attribution in incorrect cost estimation has shifted from considering straightforward, new construction contracts to complicated maintenance and repair contracts. In addition, owing to the lack of technically skilled civil engineers in the field of maintenance and repair, the number of cases of incorrect cost estimation may increase in the future. Currently, the development of public facilities is delayed, and other countries that are starting to contemplate the development of public facilities should heed Japan's problems and establish human resource development management and organisational management that can handle maintenance and repair work in the future.

\section{Management in cost estimation}

As it is challenging to eliminate incorrect cost estimations completely, risk management in the event of incorrect estimation is essential. We propose risk management based on Heinrich's Law to address this issue. As pointed out earlier, it is important to consider human resources development management and organisational management to prevent incorrect cost estimation. Furthermore, the number of facilities requiring maintenance and repair work has increased in recent years, and the types of construction have changed. Therefore, improved human resources development management and organisational management, which have not been implemented so far, are crucial. To this end, we have focused on the use of the V-mSELC model, which is an error analysis model specialising in incorrect cost estimation constructed by Nishi and Minagawa (2019). To examine whether the VmSELC model can be used for organisation management, we consider an example of organisational management of cost estimation during a flu outbreak.

\section{Risk management in the event of incorrect cost estimation}

In the case of incorrect cost estimation, appropriate risk management can be performed by using Heinrich's Law, a representative theory that provides a valuable model to understand why human error occurs (Komatsubara, 2008; Ohzeki, 2014). The law states, "There are 29 minor accidents in the shadow of one serious accident, and, furthermore, there are 300 reserve forces behind." Collecting extensive information on incidents that may lead to accidents, analysing the possible causes, and taking appropriate measures are extremely important in accident prevention. Taking Heinrich's Law into account, we believe that it is necessary to investigate not only those projects where incorrect cost estimation has been identified but also those that are currently under consideration. This will prevent further damage owing to frequent cases of incorrect cost estimation and enable appropriate risk management.

\section{Example of the error analysis model considering management}

Unlike the medical industry, for example, local governments do not carry out academic analyses using tools such as error analysis models when incorrect cost estimations occur. This is likely because error analysis models were created specifically for the medical industry and not as general model. We compared the knowledge relationships between the parties and the people involved in the healthcare industry and public cost estimation departments. Regarding the relationship between patients and doctors/nurses in the medical industry, doctors/nurses clearly have more medical knowledge than patients. In contrast, in public cost estimation departments, the knowledge of the cost estimation staff equals that of the verification staff. In other words, the relationship between the persons who could cause an error is entirely different. In addition, Kawano (2010) concluded that framework-type analysis methods are often used, but the problem is that they spend excessive time categorising the factors. When an incorrect cost estimation occurs, it is necessary to analyse its cause and quickly take corrective action. Therefore, Nishi and Minagawa (2019) built the $\mathrm{V}$-mSELC model specialising in analysing incorrect cost estimations. The basic model is presented in a diagram (see Figure 2). Each component, along with the error-inducing factors, is shown in Table 5. The position of $\mathrm{C}$ at the centre and the surrounding $\mathrm{S}, \mathrm{V}, \mathrm{E}$, and $\mathrm{L}$ components change from moment 
to moment. To prevent human error, it is necessary to adjust the centre $\mathrm{C}$ and the outer SVEL components. For that purpose, management $(\mathrm{m})$ is necessary.

We adopted the m-SHELL model as the base model of the V-mSELC model. The m-SHELL model is a model considering management that is regarded as necessary (Kawano, 1999). There are no major structural differences between these models. The components correspond to the characteristics of each field. "Hardware $(\mathrm{H})$ " was excluded from the list of components of the VmSELC model as the cost estimation typically does not use such advanced, complex hardware that is typically used in the aviation and medical industries. We decided to add the verification staff (V) as an independent component, as the relationship between the parties is closer than with other liveware.

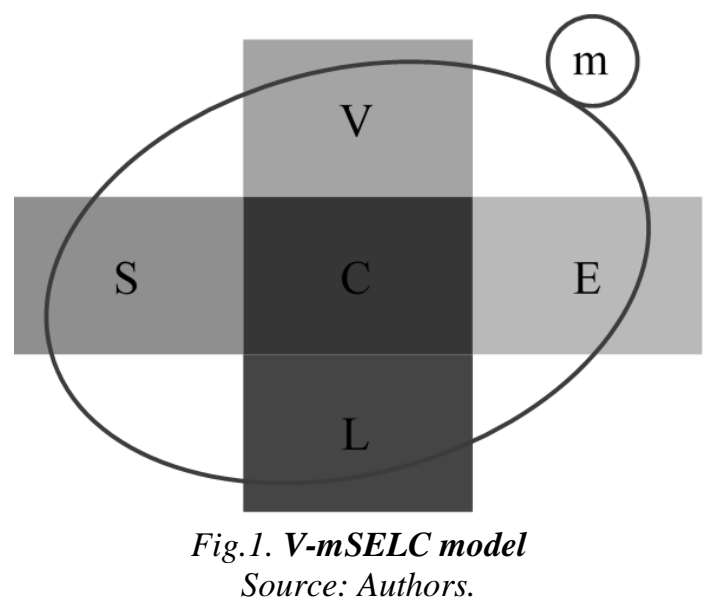

Table 5. Components of the V-mSELC model and error-inducing factors.

\begin{tabular}{|c|c|c|}
\hline \multicolumn{2}{|c|}{ COMPONENTS } & ERROR-INDUCING FACTORS \\
\hline $\mathbf{C}$ & Cost estimation staff & $\begin{array}{c}\text { Physical condition } \\
\text { Psychological situation } \\
\text { Ability }\end{array}$ \\
\hline $\mathbf{S}$ & Software & Manual \\
\hline $\mathbf{V}$ & Verification staff & $\begin{array}{c}\text { Physical condition } \\
\text { Psychological situation } \\
\text { Ability }\end{array}$ \\
\hline $\mathbf{E}$ & Environment & $\begin{array}{c}\text { Business environment } \\
\text { Time environment }\end{array}$ \\
\hline $\mathbf{L}$ & Liveware & $\begin{array}{c}\text { Communication } \\
\text { Teamwork }\end{array}$ \\
\hline $\mathbf{m}$ & Management & Organisation \\
System
\end{tabular}

Source: Authors.

An example will help explain the nature of the process. Using Table 6, we can identify the causes between the components and consider appropriate measures.

Table 6. Analytical table.

\begin{tabular}{|l|l|l|l|}
\hline Incident & \multicolumn{1}{|c|}{$\begin{array}{c}\text { Relationships between } \\
\text { components }\end{array}$} & Factors & Measures \\
\hline \multirow{4}{*}{} & $\mathrm{C}-\mathrm{V}$ & & \\
\cline { 2 - 5 } $\mathrm{C}-\mathrm{S}$ & & \\
\cline { 2 - 5 } $\mathrm{C}-\mathrm{E}$ & & \\
\cline { 2 - 5 } & $\mathrm{C}-\mathrm{L}$ & & \\
\cline { 2 - 4 } & $\mathrm{C}-\mathrm{m}$ & & \\
\hline
\end{tabular}

Source: Authors. 
The effectiveness of the V-mSELC model was confirmed by a virtual pattern that referred to a case of incorrect cost estimation in City K (Kawasaki City, 2016). The results obtained by human error analysis (Table 7) using the V-mSELC model are shown in Table 8. By using Table 7, we can identify the causes of the relationships between the five components (Cost estimation staff Verification staff, Cost estimation staff - Software, Cost estimation staff - Environment, Cost estimation staff - Liveware, Cost estimation staff - Management), and consider appropriate measures for each. As shown in Table 8, human error-inducing factors such as insufficient confirmation work, incomplete manuals, and high-pressure environments were extracted. Apparent human error-inducing factors were extracted by analysing the relationship between the components prepared in advance for the incident. Regarding incorrect cost estimation in general, the authors believe that local governments should use the V-mSELC model or an appropriate alternative scientific method to analyse human errors.

Table 7. A virtual pattern based on a case of incorrect cost estimation in City $\mathbf{K}$.

\begin{tabular}{|c|c|c|c|}
\hline INCIDENT & $\begin{array}{l}\text { RELATIONSHIPS } \\
\text { BETWEEN } \\
\text { COMPONENTS } \\
\end{array}$ & FACTORS & MEASURES \\
\hline \multirow{5}{*}{$\begin{array}{l}\text { Verification staff are } \\
\text { busy, and it takes time } \\
\text { to conduct the } \\
\text { verification. There is a } \\
\text { tendency for few } \\
\text { incorrect cost } \\
\text { estimations to be } \\
\text { caused by the unit } \\
\text { price. Therefore, the } \\
\text { Verification staff } \\
\text { decided to omit } \\
\text { detailed verification. } \\
\text { However, Cost } \\
\text { estimation staff used } \\
\text { the unit price of the last } \\
\text { fiscal year, which } \\
\text { caused the incorrect } \\
\text { cost estimation. }\end{array}$} & $\mathrm{C}-\mathrm{V}$ & $\begin{array}{l}\text { If there was no time for } \\
\text { verification, I did not confirm } \\
\text { whether to omit it. }\end{array}$ & $\begin{array}{l}\text { Ask the Cost estimation staff if } \\
\text { the Verification staff want to } \\
\text { omit the verification items. }\end{array}$ \\
\hline & $\mathrm{C}-\mathrm{S}$ & $\begin{array}{l}\text { For some reason, it was not } \\
\text { known that it was not possible } \\
\text { through the unreasonable } \\
\text { claims of the verification staff. }\end{array}$ & Create manuals for verification. \\
\hline & C-E & $\begin{array}{l}\text { The business environment and } \\
\text { time environment deteriorated } \\
\text { owing to the busy season, but } \\
\text { the coping method was not } \\
\text { publicised. }\end{array}$ & $\begin{array}{l}\text { Disseminate how to deal with } \\
\text { the business environment and } \\
\text { time environment during busy } \\
\text { periods. }\end{array}$ \\
\hline & C-L & $\begin{array}{l}\text { The Cost estimation staff did } \\
\text { not check with other staff about } \\
\text { how the Verification staff } \\
\text { handles cases when busy. }\end{array}$ & $\begin{array}{c}\text { Check with other staff regarding } \\
\text { irregular cases. }\end{array}$ \\
\hline & C-m & $\begin{array}{c}\text { When the Verification staff } \\
\text { was busy, the Cost estimation } \\
\text { staff felt the pressure. }\end{array}$ & $\begin{array}{c}\text { If it are going to verify quickly, } \\
\text { adjust it closely, and change to } \\
\text { another verification staff in } \\
\text { some cases. }\end{array}$ \\
\hline
\end{tabular}

Source: Authors.

Table 8. Relationships between Components and Error-Inducing Factors.

\begin{tabular}{|c|c|}
\hline $\begin{array}{l}\text { RELATIONSHIPS } \\
\text { BETWEEN } \\
\text { COMPONENTS }\end{array}$ & ERROR-INDUCING FACTORS \\
\hline $\begin{array}{l}\mathrm{C}-\mathrm{V} \\
\mathrm{C}-\mathrm{L}\end{array}$ & $\begin{array}{l}\text { Confirmation work by the Cost estimation staff and the Verification staff (other staff) was } \\
\text { insufficient. }\end{array}$ \\
\hline $\begin{array}{l}\mathrm{C}-\mathrm{S} \\
\mathrm{C}-\mathrm{E}\end{array}$ & The manual was incomplete. \\
\hline C-m & $\begin{array}{l}\text { The cost estimation staff was in an environment where they could feel extra time and } \\
\text { human pressures. }\end{array}$ \\
\hline
\end{tabular}

Source: Authors.

Applied adaptation of the $V$-mSELC model to human resources development management Human error analysis models have been used in many industries where the human error occurs. Nishi and Minagawa (2019) asserted that the V-mSELC model could be an effective means of developing the skills of junior staff. This is because it helps them to imagine the cost estimation 
environment. For example, a junior staff member is more likely to contemplate the risk of a miscalculation when using the V-mSELC model. To avoid incorrect cost estimations owing to the combination of $\mathrm{C}$ and $\mathrm{V}$, the correspondence of the constituent elements $\mathrm{m}, \mathrm{S}, \mathrm{E}$, and $\mathrm{L}$ can be studied. Even junior staff with little experience in cost estimation can develop an objective viewpoint by performing simulation exercises.

Table 9 presents an example of human resources development management for junior staff both with and without using the V-mSELC model. Using the V-mSELC model, we believe that it is possible to eliminate many of the cost estimation weaknesses of junior staff. We also believe that the $\mathrm{V}$-mSELC model is effective as a human resources development management tool because it enables clear visualisation of error causes and measures. Ishikawa (2010) emphasised the importance of visualisation as an effective tool in human resources development.

Table 9. Example of human resources development management for junior staff when using and not using the VmSELC model.

\begin{tabular}{|c|l|l|}
\hline & \multicolumn{1}{|c|}{$\begin{array}{c}\text { When not using } \\
\text { the V-mSELC model }\end{array}$} & \multicolumn{1}{c|}{$\begin{array}{c}\text { When using } \\
\text { the V-mSELC model }\end{array}$} \\
\hline $\begin{array}{c}\text { Physical } \\
\text { features }\end{array}$ & $\begin{array}{l}\text { It is difficult to extract incorrect causes and } \\
\text { prevention measures because experience with cost } \\
\text { estimation is quite limited. }\end{array}$ & $\begin{array}{l}\text { It is easy to extract incorrect causes and } \\
\text { prevention measures because the } \\
\text { components are given and visualised. }\end{array}$ \\
\hline $\begin{array}{c}\text { Psychological } \\
\text { features }\end{array}$ & $\begin{array}{l}\text { It is difficult to determine the causes and measures } \\
\text { for incorrect cost estimation, so junior staff feel } \\
\text { uncomfortable with cost estimation. }\end{array}$ & $\begin{array}{l}\text { It is easy to understand through } \\
\text { visualisation, so junior staff feel } \\
\text { comfortable with cost estimation. }\end{array}$ \\
\hline
\end{tabular}

Source: Authors.

\section{Applied adaptation of the $V$-mSELC model to organisation management}

The V-mSELC model can help eliminate waste and error in organisation management and prevent incorrect cost estimations. For example, it can be used to select the staff for cost estimations and perform verification by considering the type of work and the seniority of the available civil engineers in advance. Table 10 shows examples of organisation management using the V-mSELC model. The examples depicted here assume severe conditions and situations. Results are usually shown in the "factors" column in Table 7, but when using the V-mSELC model for organisational management, questions instead of results are shown in the "factors" column in Table 10. By using Table 10, we can identify the causes of the relationships between the five components (Cost estimation staff - Verification staff, Cost estimation staff - Software, Cost estimation staff Environment, Cost estimation staff - Liveware, Cost estimation staff - Management), and consider appropriate measures for each. By analysing the relationship between the components that were prepared in advance for the incident, countermeasures for clear human error inducers were extracted. Using the V-mSELC model, it is easy to visualise the factors and measures related to each component in advance and suggest appropriate organisation management strategies.

Table 10. Example of organisation management using the V-mSELC model.

\begin{tabular}{|l|l|l|l|}
\hline \multicolumn{1}{|c|}{ INCIDENT } & $\begin{array}{c}\text { RELATIONSHIPS } \\
\text { BETWEEN } \\
\text { COMPONENTS }\end{array}$ & \multicolumn{1}{c|}{ FACTORS } & MEASURES \\
\hline $\begin{array}{l}\text { The number of } \\
\text { employees taking time } \\
\text { off because of the flu has } \\
\text { increased. }\end{array}$ & C-V & $\begin{array}{l}\text { Cost estimation staff is } \\
\text { decided by Staff A, but who is } \\
\text { the Verification staff? }\end{array}$ & $\begin{array}{l}\text { The staff member who can be } \\
\text { the successor to Staff A will be } \\
\text { selected as a Verification staff } \\
\text { member because it is } \\
\text { must be completed early. }\end{array}$ \\
\hline
\end{tabular}




\begin{tabular}{|c|c|c|c|}
\hline INCIDENT & $\begin{array}{l}\text { RELATIONSHIPS } \\
\text { BETWEEN } \\
\text { COMPONENTS }\end{array}$ & FACTORS & MEASURES \\
\hline \multirow{4}{*}{$\begin{array}{l}\text { Estimating the cost of } \\
\text { working on special } \\
\text { maintenance and repairs } \\
\text { requires special } \\
\text { knowledge of cost } \\
\text { estimation and will need } \\
\text { to be continued next } \\
\text { year. } \\
\text { Only Staff A can perform } \\
\text { the unique maintenance } \\
\text { and repair work cost } \\
\text { estimation. }\end{array}$} & $\mathrm{C}-\mathrm{S}$ & $\begin{array}{l}\text { What happens if Staff } \mathrm{A} \text { is } \\
\text { transferred next year? }\end{array}$ & $\begin{array}{l}\text { In the next fiscal year, prepare } \\
\text { materials for commentary on } \\
\text { particular cost estimation so } \\
\text { that it is safe for Staff A to } \\
\text { transfer. }\end{array}$ \\
\hline & C-E & $\begin{array}{l}\text { Could Staff A get the flu in a } \\
\text { room where the flu spreads? }\end{array}$ & $\begin{array}{l}\text { Ask Staff A what kind of } \\
\text { environment facilitates cost } \\
\text { estimation, and in some cases, } \\
\text { work in another room. }\end{array}$ \\
\hline & C-L & $\begin{array}{l}\text { Might Staff A add up all the } \\
\text { time and so run out of time? }\end{array}$ & $\begin{array}{l}\text { Ask other staff members for } \\
\text { items that can be calculated } \\
\text { even if they are not Staff A. }\end{array}$ \\
\hline & C-m & $\begin{array}{l}\text { If there are many staff taking a } \\
\text { rest, do you feel the pressure } \\
\text { that Staff A cannot take a rest? }\end{array}$ & $\begin{array}{l}\text { Have Staff A take a moderate } \\
\text { break and do not put pressure } \\
\text { on him/her. }\end{array}$ \\
\hline
\end{tabular}

Source: Authors.

\section{Conclusions}

1. We classified the causes of incorrect cost estimation into two categories: "insufficient knowledge" and "other than lack of knowledge." On average, about $15 \%$ of the cases of incorrect cost estimation were owing to insufficient knowledge, while $70 \%$ and above were caused owing to other reasons. Incorrect estimations resulting from lack of knowledge required improvements in human resources development management. In the cases of faulty estimations resulting from reasons other than lack of knowledge, it was necessary to examine organisation management.

2. With the establishment of the administrative and cost estimation opinion systems, the local administration has become more transparent. When municipalities publish cost estimate information, construction companies can calculate ceiling and minimum prices for public works and point out incorrect cost estimations. This makes incorrect cost estimation a social issue.

3. The issue has shifted from simple new construction-based cost estimation to complicated maintenance and repair-based cost estimation, resulting in a complicated environment where errors are likely to occur. In addition, owing to the lack of technical skills of civil engineers in the field of maintenance and repair, the number of incorrect cost estimations is expected to continue to increase.

4. Based on Heinrich's Law, we believe that it is necessary to investigate not only projects in which incorrect cost estimations have been identified but also projects that are currently under consideration. This will prevent further damage arising out of frequent incorrect cost estimations and ensure appropriate risk management.

5. We used the V-mSELC model, an error analysis model is specialising in incorrect cost estimation constructed by Nishi and Minagawa (2019), because, as an effective human resources development management tool, it allows the clear visualisation of error causes and countermeasures. By using this model, it is easy to visualise the factors and countermeasures and implement appropriate organisation management strategies.

In terms of human resources being a valuable management resource, there are many similarities between the cost estimation departments of local governments and construction design consultancy companies worldwide. Therefore, when a construction design consultancy company makes a structural calculation error, they can analyse the cause of the error by using the V-mSELC model and can use it to determine future actions. In addition, using the V-mSELC model may have a beneficial effect on the organisational management of construction design consultancy companies because it can help improve human resources management and the professional development of young civil engineers. 
However, a limitation of this study is that it is based on the results obtained from one local government in Japan, and hence, it is necessary to accumulate experimental results from other localities as well. The V-mSELC model has not been tested in the actual workplace and should be used with caution. The model is not perfect, and if new components are added to the work environment, it will be necessary to adjust the V-mSELC model. This study is the result of research based on the ideas of the first author and does not stem from the ideas of the local government for which he works.

\section{References}

1. Ding, A. Dewalt Construction Estimating Complete Handbook. 2nd Edition. Cengage Learning, 2016.

2. Ishikawa, H. How to visualise human resources development: The key to getting ahead of the competition. Tokyo, Japan: Kadokawa Corporation, 2010.

3. Kawasaki City. Port Authority Review Report. City of Kawasaki, 2016. http://www.city.kawasaki.jp/580/page/0000075462.html [2020-07-07]

4. Kinoshita, S. Public Procurement Dismantling New Book. Economic Research Association, 2017.

5. Komada, T., Iwazuka K., \& Hiroyuki, S. Issues related to contract and cost estimation for maintenance and repair work, 2010. http://www.pwrc.or.jp/thesis_shouroku/thesis_pdf/1012-P030-033_komada.pdf [2020-07-07]

6. Komatsubara, A. Human Error. 2nd ed. Tokyo, Japan: Maruzen Publishing, 2008.

7. Max Blog. When does employee motivation go down? Max Produce Co., Ltd, 2016.

8. https://max-produce.com/blog/motivation [2020-07-07]

9. Ministry of Land, Infrastructure, Transport, and Tourism. Deterioration of social capital, 2010. http://www.mlit.go.jp/common/001121700.pdf [2020-07-07]

10. Ministry of Land, Infrastructure, Transport, and Tourism. Policy for future issues such as maintenance of port facilities, 2014. https://www.mlit.go.jp/common/001041839.pdf [2020-07-07]

11. Netscher, P. Construction Management. Create Space Independent Publishing Platform, 2017.

12. Nikkei Construction. The actual situation of the frequent occurrence of incorrect cost estimation. Nikkei Business Publications, 2010, 501, p. 37-40.

13. Nikkei Construction. Incorrect cost estimation is not disappearing. Nikkei Business Publications, 2013a, 572, p. 4447.

14. Nikkei Construction. Pitfalls of cost estimation. Nikkei Business Publications, $2013 \mathrm{~b}$.

15. Nishi, N. \& Minagawa, M. Analytical model for incorrect cost estimation in local governments in Japan. International Journal of Civil Engineering, 2019, 8(4), p. 11-20.

16. Nishi, N., Minagawa, M., Goso, T. Consideration on the incorrect cost estimation corresponding to design for public infrastructure projects in local governments in Japan. Journal of Japan Society of Civil Engineers, 2020, Vol. 76, No. 1, p. 43-51.

17. Ohashi, H. Advance Announcement of ceiling price and upper bound. The Nikkan Kensetsu Kogyo Shinbun, 2014.

18. Ohzeki, C. All of the Safety Management of the New Era. Japan Industrial Safety and Health Association, 2014.

19. Mynavi Corporation, Student Contact Editorial Department. Motivation switch off! Top 5 moments when motivation for work falls, 2017. https://gakumado.mynavi.jp/freshers/articles/50090 [2020-07-07]

20. Takagi, M. Human Error Prevention Measures in the Construction Industry. Japan: Roudochousakai Corporation, 2012.

21. Tokyo Future University. Motivation survey for the third year of working adults (The first). Tokyo, Japan: Tokyo Future University, 2018. 
Nobuo Nishi, Masaru Minagawa

\section{Viešųjų darbų išlaidų valdymas Japonijos savivaldybėse}

Anotacija

Savivaldos viešųjų pirkimų ir igyvendinimo skyriai dažnai užsiima įvairių pastatų projektų planavimo, išlaidų ịvertinimo, planuojamos kainos nustatymo, pasiūlymų, sutarčių sudarymo, statybos, priežiūros ir tikrinimo veikla. Nepaisant viso šio darbo, Japonijos vietos valdžios institucijos dažnai atšaukia projektų projektavimo ir statybos pasiūlymus dẻl neteisingo išlaidų ịvertinimo. Dẻl to stringa planuota plètra, tai atneša neigiamą viešųų pirkimų vertinimą bei neigiamai atsiliepia viešosioms paslaugoms. Tokia situacija neigiamai atsiliepia ir darbuotojų motyvacijai. Nors savivaldos institucijos atliko vidinius îsivertinimus ir buvo ieškota būdų kaip užkirsti kelią neteisingam išlaidų ịvertinimui, tačiau aiškus ir plačiai pritaikomas išlaidų vertinimo modelis nebudo dukurtas. Taip pat nebuvo suformuotos ir prevencinès priemonès. Šis tyrimas analizuoja įvairias neteisingo išlaidų ịvertinimo priežastis bei aptaria iškylančias socialines problemas. Straipsnio autoriai siūlo tobulinti žmogiškujų išteklių plètros ir organizacijos valdymo metodus, naudojant VmSELC modelį. Tai klaidų analizès modelis, skirtas neteisingam išlaidų įvertinimui. Tyrimu siekiama padèti viešujų pirkimų specialistams ir suinteresuotiems mokslininkams.

Nobuo Nishi works as a civil engineer and assistant manager in a local government in Japan. He also attends graduate school at Tokyo City University. His research interests are construction management and civil engineering.

E-mail: g1891611@tcu.ac.jp

Masaru Minagawa is the vice president and a professor of the Department of Civil and Urban Engineering, Tokyo City University. His research interests are construction management, disaster management, and information technology application in civil engineering.

E-mail: minamasa@tcu.ac.jp

Nobuo Nishi yra miestų inžinierius ir projektų koordinatorius, dirbantis vietos savivaldoje Japonijoje. N. Nishi yra Tokijo miesto universiteto mokslų daktaras, tyrinëjantis statybų vadybą bei miestų inžinerijos klausimus.

El. paštas: g1891611@tcu.ac.jp

Masaru Minagawa yra Tokijo miesto universiteto Civilinès ir miestų inžinerijos katedros vadovas ir profesorius. Moksliniai interesai apima statybos valdymas, nelaimių valdymas ir informacinių technologijų taikymas civilinèje inžinerijoje.

El. paštas: minamasa@tcu.ac.jp 